\title{
Intellectual Capital Disclosure and CSR Disclosure on Company Performance
}

\author{
Tri Retno Indaryanti, Rini Lestari*, Epi Fitriah \\ Faculty of Economics and Business, Program in Accounting \\ Universitas Islam Bandung \\ Bandung, Indonesia \\ *unirinilestari@gmail.com
}

\begin{abstract}
The current phenomenon is a decline in performance in Several mining sector companies. On the other hand, it is found that the quality and quantity of information disclosure is still low, such as intellectual capital and Corporate Social Responsibility (CSR) related to environmental activities / conditions of companies in Indonesia. This study aims to Determine the influence of intellectual capital disclosure on company performance, the influence of CSR disclosure on company performance and the influence of intellectual capital disclosure and CSR disclosure on company performance. A sample of 15 coal mining subsector companies listed on the Indonesia Stock Exchange for the 2013-2017 period was Obtained using purposive sampling. The method used in this study and verification method quantitative approach, Data were analyzed using multiple regression statistical techniques. The results showed that the intellectual capital disclosure had a positive and significant effect on company performance, CSR disclosure had no effect on company performance, and intellectual capital disclosure and CSR disclosure had a positive and significant effect on company performance. This study is expected to be a source of information for the government as a regulator of the economy in an effort to increase of the quantity and quality of intellectual capital disclosure and CSR disclosure so that it can have an impact on improving company's performance and to expand the development of economics, especially in accounting.
\end{abstract}

Keywords-intellectual capital disclosure, Corporate Social Responsibility (CSR) disclosure, and company performance

\section{INTRODUCTION}

The main objective for the company is to earn high profits. High profits obtained from the high performance of a company as well. The performance of companies that occurred in Indonesia is experiencing some decrease. In the business world development company should have a high value on some aspects and a high value in the eyes of stakeholders (citizens, consumers, shareholders, potential investors and banks). The stakeholders hope the management organization conducting activities that are considered important and report back on those activities to stakeholders. The stakeholders have a right to be provided information and assess how the activity of the company in achieving its objectives and using the performance appraisal as a basis for decision making. The company can provide the disclosure of the information in the annual report include the intellectual capital disclosure and corporate social responsibility (CSR) disclosure.

Attention to practices the intellectual capital disclosure has actually been around since the convening of the forum conducted in Amsterdam in 1999, who presented the research results of the various States with regard to the measurement and reporting of intangible assets, including on intellectual capital [1], but other studies stated that the intellectual capital disclosure has not be appeal for companies. Other than that, the development of intellectual capital in Indonesia is still limited, because the company is still using conventional based in carrying out its business activities. The companies in Indonesia have not been able to see the benefits of the company's intangible assets information related to the company's strategy [2].

This study aimed to convince the decision makers that the intellectual capital that has begun to be applied is essential to be disclosed, either to add value in the eyes of stakeholders and in an effort to improve the performance of the company. In addition to showing that the company has implemented CSR, CSR disclosure can also be used as a strategy in achieving company's goals of improving the company's performance.

Based on the above description, researchers are interested in conducting further study relating to intellectual capital disclosure and CSR disclosure as well as its influence on the company's performance.

\section{LITERATURE REVIEW AND HYPOTHESIS DEVELOPMENT}

\section{A. Intellectual Capital Disclosure on the Company's} Performance

This study will examine the influence of the intellectual capital disclosure on company performance. Intellectual capital 
disclosure is the presentation of some information is needed regarding intangible assets (intangible asstes) companies is sourced from three pillars, namely human capital, structural and customers [3]. Over time the interest in intellectual capital began to increase due to the development of a globalized economy controlled by information and knowledge [4]. There is a growing awareness that intellectual capital is a main asset for success today in the economic environment, if the assets and intellectual information is understood and managed properly can become a source of competitive advantage for businesses and stimulate the innovation leads to wealth and competition in the world economy today, as well as disclosure (Bhasin and Shaikh [5]; Ebimobowei, Felix and Wisdom [6]; Subaida [7]). There is a positive and significant relationship between the intellectual capital disclosure and ROA (Buallay [8]; Amyulianthy and Murni [9]; Altal [10]; Khairiyansyah and Vebtasvilli [11]). Thus, the first hypothesis to be tested in this study can be formulated:

H1. Intellectual Capital Disclosures has a positive and significant effect on company performance.

\section{B. Corporate Social Responsibility (CSR) disclosure on the Company's Performance}

CSR Disclosure is part of the accounting to stakeholders. Companies that have implemented CSR practices can disclose the implementation of the CSR both directly integrated in the annual report or a separate report that is often called as the Sustainability Report (Cuozzo, et al., [12] and Duff [13]). According to Deegan (Sirojudin and Nazaruddin [14]) in the perspective of legitimacy theory, a company will voluntarily report its activities if management considers that this is what the community expects. In other words, this teory put perception and public recognition as a major boost companies do CSR disclosure as an information in the financial statements. And this study is based on stakeholder theory where based on stakeholder theory, stakeholders will provide full support to the company's activities if CSR disclosure can be done properly, so that the company's goals to improve performance and achieve profits can be achieved (Jones (Lindawati and Eka [15]; Yusoff, et al. [16]; Razali, et al. [17]). Based on the description, the second hypothesis can be formulated thus:

H2. Corporate Social Responsibility (CSR) Disclosure has a positive and significant effect on company performance.

\section{Intellectual Capital Disclosure and Corporate Social Resposibility (CSR) Disclosure on the Company's Performance}

Legitimacy theory states that the organization will choose voluntarily disclose information about environmental performance, social and intellectual, over and above the obligatory request, to meet actual or recognized expectations by stakeholders. If the actual expectations or recognized by the stakeholders (shareholders, creditors, consumers, suppliers, governments, communities, analysts and other parties) are fulfilled, then it will bring the company to a value creation that will become an added value for the company (Deegan (Sirojudin and Nazaruddin [14]).

Previous reseach found that intellectual capital and CSR disclosure affect on company performance (Chintya [18]; Sagara and Chairunissa [19]). This study will reexamine the effect of intellectual capital disclosure and CSR disclosure on company performance. Based on theory and previous research that the third hypothesis in this study can be formulated:

H3. Intellectual Capital Dicslosure and Corporate Social Responsibility (CSR) Disclosure has a positive and significant effect on company performance.

\section{METHODS}

\section{A. Data and Sample of Study}

The data source used is the secondary data source such as annual report of mining sector company listed on Indonesia Stock Exchange (IDX) period 2013 to 2017. The sampling technique in this study used purposive sampling and produced 75 samples from 15 companies with a total of 5 years of study.

\section{1) Variable of study}

a) Intellectual capital disclosure: The measurement used in measuring intellectual capital disclosure is the intellectual capital disclosure index used by Singh and Zahn (Aida \& Rahmawati [20]). This index consists of 81 items which are classified into the following six categories: Resources (28 items), Customer (14 items), Information Technology (6 items), Processes (9 items), Research and Development (9 items), Strategic Statements (15 items)

This study uses content analysis techniques with the simplest form by scoring one (1) if the items disclosed and zero (0) if the items were not disclosed. Next, the scores of each item are summed to obtain the total disclosure score for each company [21]. The level ratio of the intellectual capital disclosure of each company is obtained by dividing the total disclosure score for each company by the total items in the intellectual capital disclosure index.

b) Corporate Social Responsibility (CSR) Disclosure: The measurement used in assessing CSR disclosure is the GRI-G4 standard. In the GRI-G4 standard, performance indicators are divided into three main components, namely: Economic (9 items), Environmental (34 items), Social (48 items).

In assessing outside the CSR disclosure, the items to be scored refer to the performance indicators or items mentioned in the GRI-G4 guideline. The assessment is done in measuring the extent of CSR disclosure by giving a score of 0 and 1 . Where the value of 0 for undisclosed items and 1 for items disclosed by the company [21]. The calculation formula for CSR disclosure is as follows [21]:

$$
\text { CSRDI }=\sum_{j=1}^{e} \frac{e j}{e}
$$




\section{Information:}

$\mathrm{CSRIj}=$ Corporate Social Responsibility Disclosure Index $e j=$ Number attribute analysis $(1=$ if the items disclosed; 0 $=$ if the items were not disclosed).

$e=$ The maximum number of items $\operatorname{CSR}($ Total $=91$ (maximum score))

c) Company performance: Company performance is measured by profitability ratios, namely Return On Assets (ROA). ROA compares income with total assets (equivalent, total liabilities and equity capital). ROA measures the ability and efficiency of management in using company assets to generate operating profit, the better of return on assets, the better the company's performance [18]. The ROA formula is as follows [18]:

$$
\text { ROA }=\frac{\text { Net Income After Tax }}{\text { Total Operating Assets }}
$$

2) Data analysis technique: Multiple linear regression analysis was used in this study to predict how (dependent) the dependent variable (criterion) would be, when two or more independent variables as prediator factors were manipulated (decreased value). Multiple linear regression equation set is as follows [22]:

$$
Y=a+\beta_{1} X_{1}+\beta_{2} X_{2}+\varepsilon
$$

Description:

$$
\begin{array}{ll}
Y \quad=\text { Company Performance } \\
a \quad=\text { constant Coefficients } \\
\beta_{1} \beta_{2}=\quad \text { = Regression Coefficients } \\
X_{1}=\text { Intellectual capital disclosure } \\
X_{2}=\text { CSR disclosure } \\
\varepsilon \quad=\text { Error, interference variable }
\end{array}
$$

Before testing hypotheses, the data in this study must first pass the classic assumption test to ensure that the regression model and each variable are eligible for hypothesis testing.

\section{RESULTS AND DISCUSSION}

\section{A. Results}

1) Analysis of multiple regression equations: The regression equation can be seen from the coefficients test table based on the SPSS output that has been carried out on the two independent variables namely intellectual capital disclosure and CSR disclosure on company performance and the data is declared to have passed the classical assumption test so it is feasible to do hypothesis testing. The result of multiple regression analysis:

$$
\begin{gathered}
Y=a+\beta_{1} X_{1}+\beta_{2} X_{2}+\varepsilon \\
Y=-6,796+34,285 X_{1}-5,157 X_{2}+\varepsilon
\end{gathered}
$$

Description:

$\mathrm{Y}=$ Company Performance

$X_{1}=$ Intellectual capital Disclosure

$X_{2}=$ CSR Disclosure

\section{2) Hypothesis Testing Results}

a) F test (simultaneous testing): The results of the F test calculation can be seen in table 1 as follows.

TABLE I. RESUlt of F TEST (SimultaneOUS Testing)

\begin{tabular}{|c|l|c|l|l|l|c|}
\hline & \multicolumn{1}{|c|}{ Model } & $\begin{array}{c}\text { Sum of } \\
\text { Squares }\end{array}$ & df & $\begin{array}{c}\text { Mean } \\
\text { Square }\end{array}$ & F & Sig. \\
\hline 1 & Regression & 548.191 & 2 & 274.096 & 4.915 & $0.010^{\mathrm{a}}$ \\
\hline & Residual & 3959.423 & 71 & 55.767 & & \\
\hline & Total & 4507.614 & 73 & & & \\
\hline
\end{tabular}

From the results of the regression analysis in the table above it can be seen that together the two independent variables have a significant influence on the dependent variable. This can be proven by the acquisition of Sig is smaller than 0.05 which is $0.01<0.05$. So it can be concluded that the variables of intellectual capital disclosure and CSR disclosure simultaneously affect the company's performance variables as measured by ROA. That is, $\mathrm{H}_{\mathrm{o}}$ is rejected and $\mathrm{H}_{\mathrm{a}}$ is accepted. Thus, intellectual capital disclosure and CSR disclosure affect the company's performance.

b) T Test (Parcial Test): The partial test results of the influence of intellectual capital disclosure variables and CSR disclosure on company performance variables measured by ROA are shown in table 2 as follows.

TABLE II. Result OF T Test (PARCIAL TEST) COEFFICIENTS $^{\mathrm{A}}$

\begin{tabular}{|l|l|l|l|}
\hline \multicolumn{1}{|c|}{ Model } & \multicolumn{1}{c|}{ Coefficient } & \multicolumn{1}{c|}{ Std. Error } & Sig. \\
\hline (Constant) & -6.796 & 3.346 & 0.046 \\
\hline Intellectual Capital & 34.285 & 11.065 & 0.003 \\
\hline CSR & -5.157 & 6.398 & 0.423 \\
\hline \multicolumn{3}{|c|}{ a. Dependent Variable: Company Performance }
\end{tabular}

(Source: Secondary data were processed using SPSS V.17)

The effect of each intellectual capital disclosure and CSR disclosure variable on company performance variables can be seen from the direction of the sign and the level of significance (probability) and by comparing $\mathrm{t}$ counts and tables with a significance level (probability) of 5\% (0.05). The t table value obtained in this study is 1.66571 with a df of 71 . Based on the above table, the results of hypothesis testing of each independent variable partially on the dependent variable can be analyzed as follows.

\section{B. Discussion}

1) Intellectual capital disclosure on company performance: Based on the results of statistical tests using the application SPSS v.17 shows that the intellectual capital disclosure affects the company's performance. The intellectual capital disclosure variable has a significant value of 0.03 smaller than (a) $=0.05$. So it can be concluded that the intellectual capital disclosure has a positive and significant 
effect on company performance as measured by ROA (Return on Assets). That is, the more companies disclose their intellectual capital information will increasingly add value to the company which will have an impact on improving company performance which in this study is measured by ROA. ROA measures the company's ability to generate net income based on a certain level of assets. The better the return on assets, the better the company's performance. Then every additional index of intellectual capital disclosure will increase the company's ROA as well.

In line with the results and the year in which this study was conducted, since 2013 companies in Indonesia have been able to see the role of intellectual capital and the benefits of disclosing intellectual capital in their annual reports. The more companies disclose information about their intellectual capital will have an impact on improving the performance of their companies.

Based on the findings above, the first hypothesis about the effect of intellectual capital disclosure on company performance can be accepted.

2) Corporate Social Responsibility (CSR) disclosure on company performance: Statistical tests conducted using the SPSSv.17 application give results that CSR disclosure variable had a significant value of 0.42 greater than $(a)=0.05$ so it can be concluded that CSR disclosure had no significant effect on company performance. This means that the amount of information about CSR disclosed in the company's annual report has no impact on company performance as measured by ROA.

In the past few years, companies still use CSR information disclosure as a strategy to improve company performance However, currently the company's performance is not a determinant of the company to disclose its CSR, the company is forced by shareholders and the public to carry out and disclose their CSR activities regardless of the state of their financial status [23]. Stakeholders consider that CSR information has become a part that is definitely available in the annual report because CSR is an organizational obligation for all stakeholders as stated in the Financial Services Authority Regulation No. 29 / POJK.04 / 2016 article 4 which states that the annual report must contain at least the social and environmental responsibility of the issuer or public company. Other reasons that can be explained in relation to the above research results that there is no significant effect between CSR disclosure and company performance are as follows: mining energy needs are increasing, especially coal, where coal is the most important source of energy for electricity generation and serves as a primary fuel for steel and cement production, causing customers to continue to buy coal from coal companies regardless of whether the company discloses or not information about CSR, the higher the CSR disclosure index by the company, does not cause an increase in return on assets for the company's operating activities or ROA obtained by the company. Assets in a mining company need to be constantly updated and added. An increase in assets if not offset by profit will result in a low ROA ratio, and, this study found that the level of CSR disclosure of coal mining companies is still relatively low, because the number of CSR disclosure indexes they disclose is below the average. CSR, although in this study found no effect on company performance, it is important to apply and disclose because the company's activities are not limited to only benefiting certain parties but must pay attention to the environmental conditions inside and outside the company

3) Intellectual capital disclosure and Corporate Social Responsibility (CSR) disclosure on company performance: Based on statistical tests using SPSS V.17, the results obtained indicate the intellectual capital disclosure variable and CSR disclosure together have a significant value of 0.01 less than (a) $=0.05$ so it can be concluded that intellectual capital disclosure and CSR disclosure have a significant effect on company performance. This means that if intellectual capital and CSR information are jointly disclosed, it will have an impact on improving company performance, which in this study is measured by ROA.

The information in the company's annual report is very useful for stakeholders in making decisions. Companies will voluntarily disclose information about their environmental, social and intellectual performance beyond their mandatory requests because the company expects that if stakeholders receive the information they expect, it will create a good value creation for the company. By disclosing information about intellectual capital and CSR in the company, stakeholders will learn how the company manages its human, structural and customer capital and how the company is responsible for the surrounding environment and the sustainability process to adapt to environmental changes and challenges.

Disclose information can be used as one of the main assets for success today in the economic environment, if information can be understood and managed well it can be a source of competitive advantage for business and stimulate innovation leading to wealth and competition in today's world economy.

\section{CONCLUSION}

Based on research on intellectual capital disclosure and CSR disclosure on company performance as measured by ROA in mining sector companies listed on the Indonesia Stock Exchange (IDX) year 2013-2017, the following conclusions can be drawn:

- The intellectual capital disclosure has a positive and significant effect on company performance as measured by ROA.

- The Corporate Social Responsibility (CSR) disclosure has no effect on company performance as measured by ROA.

- The Intellectual capital disclosure and CSR disclosure have a positive and significant effect on company performance as measured by ROA. 


\section{REFERENCES}

[1] I. Ulum, "Investigasi Hubungan antara Kinerja Modal Intelektual dan Praktik Pengungkapannya in Laporan Tahunan Perusahaan," Jurnal Ekonomi Bisnis, Vol. 17, No. 1, 2012.

[2] I. Ulum, "Intellectual Capital Disclosure: Suatu Analisis dengan Four Way Numerical Coding System,” JAAI, Vol. 19, No. 1, pp. 39-50, 2015.

[3] Hery, Analisis Laporan Keuangan, Jakarta: Bumi Aksara, 2012.

[4] S. Santosa, "Pengaruh Intellectual Capital dan Pengungkapannya Terhadap Kinerja Perusahaan,” Jurnal Akuntansi dan Keuangan, Vol. 14, No. 1, 2012.

[5] S. Bhasin, "Intellectual Capital Disclosure in the Annual Reports: a comparative study of the India and Australian IT- Corporation," International Journal of Managerial and Financial Accounting, Vol. 3, No. 4, pp. 379-492, Jan, 2011.

[6] A. Ebimobowei, S.T. Felix, and S.C. Wisdom, "Human Resource Development Mechanism and the Performance of Public Sector Accountants' in Nigeria," Current Research Journal of Social Science, Vol. 4, No. 3, pp. 246-255, May, 2012.

[7] I. Subaida, Nurkholis and E. Mardiati, "Effect of Intellectual Capital and Intellectual Capital Disclosure on Firm Value," Jurnal Aplikasi Manajemen, Vol. 16, No. 1, 2018.

[8] A.M. Buallay, "The Relationship Between Intellectual Capital and Firm Performance," Corporate Governance and Organizational Behavior, Vol. 1, Issue 1, 2017.

[9] R. Amyulianthy and Y. Murni, "Intellectual Capital and Firm Performance", International Journal of Business and Management Invention," Volume 4, Issue 9, September, 2015, pp: 13-23.

[10] A.F. Altal, "The Impact of Intellectual Capital Disclosure on Market Value: An Empirical Study on Jordian Pharmaceutical Manufacturing Companies Listed in Amman Stock Exchange," Journal of Social Science, Vol. 5, No. 3, July, 2016.

[11] Khairiyansyah and Vebtasvilli, "Relationship between Intellectual Capital with Profitability and Productivity in Indonesian Banking Industry," Jurnal Keuangan dan Perbankan, Vol. 22, No. 1, 2018.

[12] B. Cuozzo, J. Dumay, M. Palmaccio, and R. Lombardi, Intellectual Capital Disclosure: A Structured Literature Review," Journal of Intellectual Capital, Vol. 18, No. 1, pp: 9-28, 2017.
[13] A. Duff, "Intellectual Capital Disclosure: Evidence from UK Accounting Firms," Journal of Intellectual Capital, Vol. 19, No. 1, June, 2018.

[14] G.A. Sirojudin and I. Nazarudin, "Pengaruh Modal Intelektual dan Pengungkapannya terhadap Nilai dan Kinerja Perusahaan,” Journal of Accounting and Investment, Vol. 15, No. 2, 2018.

[15] A.S.L. Lindawati and M.E. Puspita, "Corporate Social Responsibility: Implikasi stakeholder dan Legitimay Gap in Peningkatan Kinerja Perusahaan,” Jurnal Akuntansi Multiparadigma, Vol, 6 No. 1, 2015.

[16] H. Yusoff, S.S. Mohamad and F. Darus, "The Influence of CSR Disclosure Structure on Corporate Financial Performance: Evidence from Stakeholders Perspectives," in Procedia Economics and Finance Vol. 7, pp. 213-220, 2013.

[17] M.W.M. Razali, W.H.S. Sin, J.A. Lunyai, J.Y.T. Hwang and I.Y.M Yusoff, "Corporate Social Responsibility Disclosure and Firm Performance of Malaysian Public Listed Firms," in Internal Business Reasearch, Vol. 11, No. 9, 2018.

[18] Chintya, "Pengaruh Intellectual Capital dan Corporate Social Responsibility Disclosure terhadap Kinerja Perusahaan", Jurnal Ekonomi, Manajemen, Akuntansi, Vol. 21, No. 1, March, 2019.

[19] Y. Sagara and C. Chairunissa, "The Effect of Intellectual Capital Measurement, the Corporate Social Responsibility Disclosure and the Firm's Capital Structure on the Financial Performance," Conference Paper on International Conference on Islamic Finance, Economics and Business, Volume 2018.

[20] R.N. Aida and E. Rahmawati, "Pengaruh Modal Intelektual dan Pengungkapannya Terhadap Nilai Perusahaan: Efek Intervening Kinerja Perusahaan," Journal of Accounting and Investment, Vol. 16, No. 2, pp. 96-109, 2015

[21] A. Dias, L.L. Rodrigues, R. Craig, and M.E. Neves, "Corporate Social Responsibility Disclosure in Small and Medium-sized Entities and Large Companies", Social Responsibility Journal, 2018.

[22] Sugiyono, Metode Penelitian Pendidikan (Pendekatan Kuantitatif, Kualitatif, dan R\&D), Bandung: Alfabeta, 2015.

[23] S. Wuttichindanon, Corporate Social Responsibility Disclosure-Choices of Report and Its Determinants: Empirical Evidence from Firms Listed on the Stock Exchange of Thailand," Kasetsart Journal of Social Sciences, Vol. 38, No. 2, pp. 156-162, 2017. 